\title{
Post-basic nursing students' reflections on their experiences of dialogic mediation
}

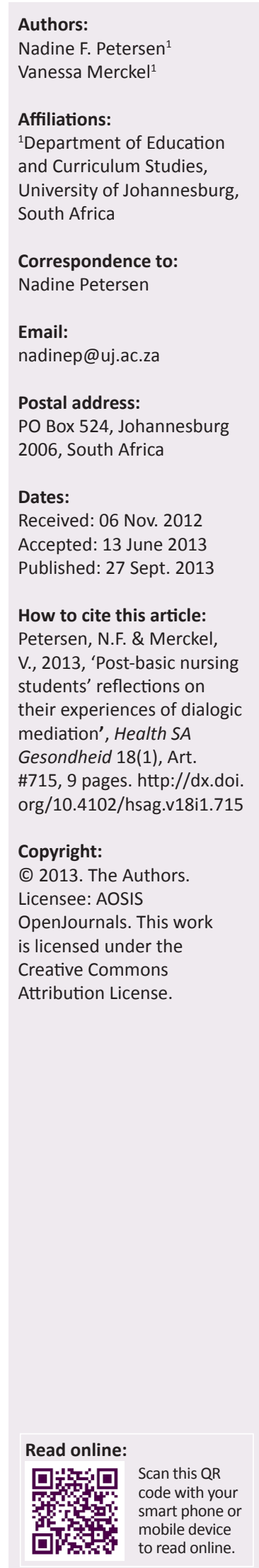

This article presents post-basic nursing students' reflections on the way they experienced the pedagogy of dialogic mediation. The study addressed current debates about appropriate teaching methodologies for students in such a degree course and the role of the nurse educator in this regard. The authors used a qualitative research approach and posed the following research question: What are students' reflections of their experiences of dialogic mediation and the influence of this on their ideas of teaching and learning? The study involved a cohort of students $(n=248)$ who were enrolled in a semester-long course in a post-basic nursing degree at a South African university. They were asked to respond to three open-ended questions regarding their experiences of a course that required engagement with a new teaching and learning strategy which expected active involvement. Data were collected from students' written reflections and were analysed by searching for recurring themes and patterns. The findings revealed that students experienced extreme levels of frustration at the beginning of the course as their existing ideas about teaching and learning were challenged. They also found the new teaching techniques associated with this pedagogy to be demanding. However, once they understood the underlying principles and ideas, they began to understand the implications for their own learning and teaching practices.

Hierdie artikel handel oor nabasiese-verpleegstudente se nadenke oor die wyse waarop hulle die pedagogie van dialogiese bemiddeling ervaar het. Hierdie studie het aandag gegee aan huidige debatte oor geskikte onderrigmetodologieë vir studente in so 'n graadkursus en die rol van die verpleegkundige-opvoeder in hierdie opset. Die outeurs het 'n kwalitatiewe navorsingsbenadering gebruik en het die volgende navorsingsvraag gestel: Wat is studente se nadenke oor hul ervarings van dialogiese bemiddeling en die invloed daarvan op hul idees van onderrig en leer? Die studie het ' $n$ spesiefike kohort studente $(n=248)$ wat ingeskryf is by 'n semesterkursus in 'n nabasiese verpleeggraadprogram aan 'n Suid-Afrikaanse universiteit ingesluit. Hulle is gevra om op drie oop vrae te reageer oor hul ervarings van ' $n$ kursus wat betrokkenheid by ' $n$ nuwe onderrig- en leerstrategie vereis en waar aktiewe deelname verwag word. Data is uit studente se skriftelike nadenke ingesamel en is ontleed deur vir herhalende temas en patrone te soek. Die bevindings het getoon dat studente uiterste vlakke van frustrasie aan die begin van die kursus ervaar het, aangesien hul bestaande onderrig en leer uitgedaag is. Hulle het ook die nuwe onderrigtegniek wat met hierdie pedagogie gepaardgaan veeleisend gevind. Nadat hulle egter die onderliggende beginsels en idees verstaan het, het hulle begin om die implikasies van hul eie leer- en onderrigpraktyke te verstaan.

\section{Introduction}

\section{Problem statement}

In South Africa, many mature post-basic nursing students come from an educational background where passive reception of information is the dominant pedagogy. Presently, however, nurse educators are being encouraged to create learning situations and classroom conditions that foster critical thinking by using interactive dialogue as a method of instruction (Harvath 2008) and to display the appropriate kind of teaching behaviour to students (Van Dyk et al. 2005) that reflects this. The pedagogy expounded on in this article is founded on a constructivist conceptualisation of learning, which requires students to reflect actively on their previous, and current, knowledge and experience in the meaning-making process. In dialogic teaching 'meaning making' describes the process of learning and thus the teacher as facilitator makes meaning of the content in interaction with the students in the teaching process (Merriam, Caffarella \& Baumgartner 2007:294-296). The authors worked in this post-basic degree course, which focused on dialogic education principles with a two-fold purpose: they provided students with the basic tools regarding how to structure a course using dialogical teaching principles and they also displayed the actions associated with the practice of dialogic teaching, so that students learned about implementing the techniques through their own interaction with the authors as teachers in the classroom environment. 


\section{Background}

This article is based on a study of post-basic nursing students' reflections of a teaching pedagogy that promotes a learning-centred form of teaching and learning known as dialogic mediation. Dialogic mediation integrates the concepts of 'dialogue' and 'mediation', using learning tasks as a design and organising principle. As pedagogy, it proceeds from the premise that the critical discussion and exchange of ideas between educator(s) and student(s) about course content will increase the efficacy of learning. The authors' work on dialogue draws on the work of Burbules and Bruce (2001), where dialogue entails more than a mere conversation or exchange of ideas. Dialogue serves to form a relationship of respect between the educator and students; a relationship characterised by cooperation, exploration and the interrogation of formal knowledge (learning content) that requires both parties in the dialogue to think and reason in a reciprocally-beneficial way. Dialogic mediation as pedagogy thus effectively redefines the roles of the educator and the student in the teaching-learning interaction, in that the educators take up a position of learning as they interact with their students. They thus work in tandem to ensure that the outcomes of the course are achieved, thereby emphasising the contributions of each to the process of cooperative meaning making in the course.

\section{Trends}

There is an existing demand for the teaching of criticalthinking skills in nursing education, both internationally (Tanner 2009; Worrell \& Profetto-McGrath 2007; Yuan, Williams \& Fan 2008) and in Southern Africa (Chabeli 2007; Van Dyk et al. 2005). According to Harvath (2008:535), the nurse educator should encourage students to question professional concepts and practices. These considerations are particularly valid in a context where the lecture method predominates, as with nursing education (Forbes \& Hickey 2009:4). The predominance of content-laden curricula transmitted mainly through lectures might fail to provide appropriate critical-thinking learning experiences. Rowan et al. (2007:132) explore a scaffold approach to learning through problem-based pedagogy for nursing education in South Africa that draws on theories of cooperative, mediated and reflective learning, whilst Tanner (2009:299) advocates curricula that develop students as active participants, who focus on the efficacy of reflection for learning. In South Africa, Chabeli (2007:69-70) argues against traditional methods of teaching and assessment with the rejoinder that they do not foster critical thinking. Instead, Chabeli (2007:70) proposes the adoption of teaching approaches that include interactive dialogue, cooperation and collaboration amongst students.

This view of learning in which students actively create meaning with their teachers has been informed by the views of various scholars, in particular Shor and Freire (1987) and Vella (2008) and of proponents of active learning (Jeffries 2005; Mickelson, Kaplan \& MacNeily 2009; Russell, Comello \& Wright 2007). Furthermore, the use of small-group interaction and open questions facilitates dialogue that is characterised by respect, deep engagement with, and critical reflection on, the learning content and its implication for their practice. Students are supported in the creation of a context that fosters meaningful engagement in the educational setting. The focus is on the process of learning as a meaningmaking activity, which involves the educator as mediator and students as active contributors.

\section{Objectives}

The research objectives were sparked by the authors' interest in understanding the students' experience of a pedagogy that promotes dialogue and mediation and uses learning tasks as a design and organising principle, as well as by how it influenced their ideas about teaching and learning. Despite the success rate of the course (in the last five years the course has had a throughput rate of between $75 \%$ and $80 \%$ ), students complained throughout the first half of the semester about the difficulties they were experiencing with the pedagogy. The research objectives were encapsulated in the overall research question guiding this study: What are students' reflections of their experiences of dialogic mediation and its influence on their ideas about teaching and learning? In creating a context for this research in a body of current research, the authors drew on key trends in the literature which speak to learning through a problem-based pedagogy for nursing education, promoting curricula that require active participation from students and adopting teaching approaches that include interactive dialogue, cooperation and collaboration amongst students. Based on this, they argue that nurse educators need to develop and test innovative teaching methodologies as well as to evaluate current teaching models. In order to provide contextualisation for the reader, the authors present a brief outline of the course design and examples of learning tasks in order to illustrate what was expected of students in terms of the teaching pedagogy in action.

\section{Contribution to the field}

On a theoretical level, in putting forward dialogic mediation as pedagogy for developing critical thinking skills (Popil 2011) for students in a post-basic degree course, the authors hope to show how constructivist views of knowledge and learning (Garrison \& Archer 2000:92; Merriam et al. 2007:292) can be used to inform curriculum design for nursing students. On a practical level, the article provides the actual course outline and strategies used within the course so that readers may evaluate the veracity and efficacy of the course design and implementation for teaching nursing students critical-thinking skills and active-learning methods in a South African context.

\section{Research method and design}

This study can be classified as a generic qualitative study (Merriam 2009), also known as 'non-categorical qualitative research' (Thorne, Kirkham \& MacDonald-Emes 1997) and as the 'fundamental qualitative method' (Sandelowski 2000). The study was aimed at capturing aspects of the lives of participants by analysing their 'intentions, beliefs, values and 
reasons, meaning making and self-understanding' (Henning, Van Rensburg \& Smit 2004:20) from their own perspectives. The purpose of generic qualitative studies is to 'discover and understand a phenomenon, a process, or the perspectives and worldviews of the people involved' (Merriam 2009:22) and is growing in popularity in fields such as education, medicine and nursing. The focus in generic qualitative studies is on the identification of patterns and categories within data which are interpreted to explain phenomena. The students from whom the data were collected had already completed their basic training and were enrolled in a semester-long course in a post-basic nursing degree programme at a South African university, to further their careers.

\section{Site and setting}

The article presents a practical course outline in order to illustrate how students are taken through the various phases of a learning-centred form of teaching and learning (known as dialogic mediation) and the various learning units that comprise the course as well as the purpose of each. The course was divided into four broad phases, which were clustered into six academic units (see Table 1 below). Phase one consisted of assisting students in the examination of their existing knowledge and experiences of teaching and learning. In the second phase, students were introduced to the constructivist views of knowledge and learning (Garrison \& Archer 2000:92; Merriam et al. 2007:292) that informed dialogic mediation. In the third phase, the educator and students drew on the content of the previous phase to explore the essential components of the pedagogy, whilst in the fourth phase, students were invited to consolidate and implement all they had learned.

In order to engage students actively with the learning content, learning tasks were used in order to structure the planning of student and educator activities for class meetings and out-ofclass work. A learning task is a task for the students, based on an open question, accompanied by the resources they need in order to respond to the question (Vella 2008:19). The resources contain learning content, which was presented to them in a variety of ways, ranging from handouts to classroom lectures. The learning tasks required them to interrogate the learning content immediately and each lesson consisted of a series of different types of learning tasks, with which they were asked to engage individually or in small groups of three to five. Some learning tasks invited students to clarify their existing views, also called inductive tasks, or called for the summary or analysis of important sections of the learning content (input tasks) (see Table 2 for examples of learning tasks). Other tasks required critical analysis, reflection, problem identification, problem solving, explanation, application and synthesis (implementation, summary and integration tasks) (Gravett 2005:62-65; Vella 2008:53). The tasks structured the educators' dialogue with students and the students' dialogue with each other. A different series of learning tasks was used to continue the dialogue about the course content with students outside the classroom environment as class time was relatively limited. Students were required to collate their answers to these tasks and submit for assessment, one compilation (in the form of a workbook) half-way through the course and then another towards the end.

\section{Data collection}

Data were collected anonymously at the end of the course (May 2011) via written responses to three open-ended questions from students $(n=248)$ who were part of a larger cohort of 260 students enrolled in a semester-long course in a post-basic nursing degree programme. The participants in this study were the ones who agreed voluntarily to partake in this study and from whom data were collected. The authors aimed at gaining an understanding of student experiences from their perspectives; from their initial frustrations at the beginning of the course through to their experiences of the course at the end. Student responses to the following questions comprised the data for this study:

1. Compare your accomplishments with what you had hoped for and expected at the start of this course.

2. What did you find difficult or frustrating and what did you enjoy? Why?

3. Provide a short summary of your learning journey.

Written data were collected from students as we reasoned that it provided a non-threatening way for students to be helped to explore their own struggles and successes within the course. We also expected that students would be in a position to think critically about their own learning journey over the course of the semester and to determine how it impacted on their ability to acquire, transfer and apply mastered knowledge.

\section{Data analysis}

Data were analysed first by the individual researchers in isolation, then together by the two authors to make sense of the data gathered. This process followed a combination of the

TABLE 1: Brief outline of course.

\begin{tabular}{|c|c|c|}
\hline Phases & Learning units & The purpose of the unit \\
\hline Phase 1 & Unit One: Learning & $\begin{array}{l}\text { Exploring students' existing beliefs about learning. Teaching students about } \\
\text { constructivist approaches to learning. }\end{array}$ \\
\hline \multirow[t]{3}{*}{ Phase 2} & Unit Two: Dialogic teaching & $\begin{array}{l}\text { Focus on learning-centred teaching and the roles of the educator and students in this } \\
\text { process to guide students' own design of learning events. }\end{array}$ \\
\hline & Unit Three: Dialogic teaching: small-group interaction and open questions & Specific strategies in the implementation of learning-centred teaching. \\
\hline & Unit Four: A dialogic lesson plan and specific teaching devices & $\begin{array}{l}\text { Examples of lesson plan structure building on information from Units } 1,2 \text { and } 3 . \\
\text { Exploring the use of various instructional devices (case study, demonstration, etc.). }\end{array}$ \\
\hline Phase 3 & Unit Five: The seven steps of planning & $\begin{array}{l}\text { Using a specific planning model to teach students how to plan a lesson or series of } \\
\text { lessons (learning events). }\end{array}$ \\
\hline Phase 4 & Unit Six: Integrated application and reflection & $\begin{array}{l}\text { Integrating information from Units } 1-5 \text {. Reflection on initial beliefs and practices after } \\
\text { the course. }\end{array}$ \\
\hline
\end{tabular}


processes of making sense of qualitative data as expounded by Henning et al. (2004) and Merriam (2009), firstly involving coding verbatim extracts from the student responses for each question and then clustering these codes into a number of categories. Thereafter, the categories were collapsed into themes from which pattern(s) could be identified and these, in turn, formed the basis of the findings. In this section, an example is provided of how this process was effected, using a sample of data in order to illustrate the flow of data analysis (Table 3). At the beginning of the data analysis process, for instance, more than 200 codes were obtained initially from student responses. Utterances with similar meanings were clustered and codes were again assigned. In this process, the researchers tried to stay as close to the meaning of the data as possible. For instance, in Table 3, the student utterances and their related (clustered) codes reflect their struggle to overcome their initial expectations of the course. Thereafter, the codes were utilised to form categories, which were labeled conceptually. This is reflected as 'Learning as listening through lectures that provide information'. From this point onwards, categories could be clustered and written up descriptively as themes, which allowed connections to be made between the various themes. An example of such a theme is included in the last column of Table 3.

\section{Presentation of findings}

The findings of the study are summarised in Table 3 in a manner which reveals the stages of students' reflections through a chronological route of engaging with dialogic mediation as pedagogy and its influence on their ideas about teaching and learning as captured in the research question.

\section{Students' initial frustrations were in opposition to their existing ideas about teaching and learning}

Most of the students' feedback indicated that the main frustration was experienced at the beginning of the course, when their initial expectations and existing ideas about what teaching and learning entailed were challenged. This challenge can be compared to the notion of 'cognitive dissonance' (Horii 2007:373), also known as a 'disorienting dilemma' (Mezirow 2003), which serves as a catalyst for students to acknowledge the inadequacy of their current ideas in order for them to move toward new understandings. It also corresponds with the process nursing students have been found to undergo when they have to 'unlearn' existing ways of doing (Gravett \& Petersen 2009). In this study it means that students would be placed in a position in which they would have to face the unsuitability of their old views, knowledge, perceptions and experiences of learning and the dismay and consternation they feel during this process (Kuiper \& Pesut 2004:384). This is evident in their initial responses.

In each lesson, as the pedagogy-in-action was delivered, students were encouraged, via learning tasks, to adopt an active role in their learning. The dialogic nature of strategies (such as the learning tasks in this course) finds resonance with the work of Taylor (2007:178-179), who argues that such strategies can help promote students' development of critical

TABLE 2: Examples of learning tasks in Unit 1 of the course.

\begin{tabular}{|c|c|c|}
\hline Learning Task & Examples of learning tasks & Type of learning task \\
\hline 1.1. Personal beliefs about learning & $\begin{array}{l}\text { Write your personal beliefs about learning, including a description of what you think learning is and } \\
\text { how you know when you have learned something (approximately } 1 / 2 \text { page). }\end{array}$ & Inductive learning task \\
\hline 1.2. More about learning & $\begin{array}{l}\text { Examine the section in the textbook (Gravett } 2005 \text { ) entitled 'Learning from a constructivist } \\
\text { perspective'. } \\
\text { 1.2.1 Summarise your understanding of the concept learning as it is put forth in these readings } \\
(3 / 4-1 \text { page). } \\
\text { 1.2.2 Compare your personal belief (Learning Task } 1.1 \text { ) and the central ideas of the text books } \\
\text { (Learning Task 1.2.1). }\end{array}$ & Summary and integration tasks \\
\hline
\end{tabular}

TABLE 3: An illustration of the flow of data analysis: 'Students' initial expectations'.

\begin{tabular}{|c|c|c|c|}
\hline Verbatim extracts from students' responses & Codes & Categories & Theme \\
\hline $\begin{array}{l}\text { '... learning for me was always about sitting and } \\
\text { listening' }\end{array}$ & Learning as listening & $\begin{array}{l}\text { Learning as listening through lectures } \\
\text { that provide information. }\end{array}$ & $\begin{array}{l}\text { Students struggle with their initial } \\
\text { expectations of the course and are frustrated } \\
\text { at the prospect of having to assume an active } \\
\text { role in the teaching-learning process. }\end{array}$ \\
\hline $\begin{array}{l}\text { 'I thought that this module would be lectured like all } \\
\text { the other modules' }\end{array}$ & Expecting only lecturing & $\begin{array}{l}\text { Learning as listening through lectures } \\
\text { that provide information. }\end{array}$ & $\begin{array}{l}\text { Students struggle with their initial } \\
\text { expectations of the course and are frustrated } \\
\text { at the prospect of having to assume an active } \\
\text { role in the teaching-learning process. }\end{array}$ \\
\hline $\begin{array}{l}\text { 'The teacher needed to be the sole provider of } \\
\text { information' }\end{array}$ & $\begin{array}{l}\text { Expecting educator to provide } \\
\text { information }\end{array}$ & $\begin{array}{l}\text { Learning as listening through lectures } \\
\text { that provide information. }\end{array}$ & $\begin{array}{l}\text { Students struggle with their initial } \\
\text { expectations of the course and are frustrated } \\
\text { at the prospect of having to assume an active } \\
\text { role in the teaching-learning process. }\end{array}$ \\
\hline
\end{tabular}


TABLE 4: Findings from the data analysis process.

\begin{tabular}{ll}
\hline Findings & Data analysis \\
\hline Finding 1 & $\begin{array}{l}\text { Students initially express their frustrations with a pedagogy that expected them to take an active part in their own learning when they were accustomed to more } \\
\text { passive forms of learning. }\end{array}$ \\
Finding 2 & Students show a movement from frustration with dialogic mediation to understanding the value of the pedagogy. \\
Finding 3 & Students begin to appreciate the value of small group interaction. \\
\hline
\end{tabular}

reflection on their learning. However, given their previous experience of predominantly transmission teaching, it is not surprising that they were expecting an educator who would do all the work. In essence, they anticipated that they would be 'talked to' about the learning content, which they were expecting to receive passively. This is illustrated by excerpts from student reflections. As the responses were anonymous, no details about the respondents were recorded:

'In the beginning of the course, it was hard ... learning and teaching for me was always about sitting and listening to the teacher to give you information ... and taking notes and producing information just as it is on the transparencies, and then writing tests and examinations.' (Anonymous)

'I thought this module would be lectured like all the other modules with an assignment and a test ... I thought I would sit and be "told" how to become an educator, and then regurgitate what I was told and get my qualification.' (Anonymous)

'My initial view of teaching was that the teacher needed to be the sole provider of information and that students' input was irrelevant.' (Anonymous)

Students were, for this reason, surprised at our expectation that they would play an active part in the learning process:

'I suddenly had to come out of my comfort zone of being "stuffed with knowledge" while folding my arms and at some stage dozing off ... I was accustomed to a spoon-feeding and an easy-come-easy-go system ... what a rude awakening for me!' (Anonymous)

Overall, this finding speaks to research in the field of nursing education that addresses the role of self-reflection in terms of addressing the underlying assumptions of existing classroom practice and its effects on student learning (Ruth-Sahd 2003).

\section{Moving from frustration to understanding the value of the pedagogy}

Students reported that they found the new teaching techniques associated with this pedagogy to be demanding. They also indicated that only when they understood the underlying principles and ideas associated with dialogic mediation did they realise the implications for their own learning as students and for their practice as professionals. The findings correspond with Mezirow's (2003) notion of 'discriminant reflexivity' which describes how students develop the ability to assess the effectiveness (or not) of their perceptions. It also allows them to be able to identify the reasons why they are reacting in a particular way and how this affects their actions. This would account for the students' extreme frustration at the beginning of the course and their movement toward acceptance as they began to understand the purpose of the tools and strategies used.

For instance, students initially did not see the significance of their input in the teaching and learning process and in the first weeks of the course they were reluctant to express their views in class. They wrote in their reflections that they were afraid that they did not have anything of value to add, or that they were afraid of ridicule:

'I come from a traditional background of lecturing where the teacher was the only expert and I would never challenge any idea ... what do I know?' (Anonymous)

These findings are akin to the arguments made by Brookfield (2005:118), who indicated that when first exposed to discussions students often do not recognise that they may be involved in 'group creation of knowledge' because they are most afraid that they are being judged about their 'familiarity [or lack thereof] with the course content'. Another student commented:

'The unit dialogic teaching [see Table 1] put things into perspective. Like I never knew why educators like to ask questions before even teaching us ... so after going through that unit now, I have more understanding. They are trying to find out what students already know.' (Anonymous)

In addition to ascribing to the idea of an omniscient educator, the students held on to the view of a silent student who only listens and takes notes during a lesson. For instance, one student reflected:

'I thought that if students are just passive and the educator pushes the information down their throats then the student will internalise it. My attitude has changed drastically and I now appreciate the importance of student input.' (Anonymous)

Students were also very frustrated at the educators' insistence that their summaries be written in their own words. Virtually all the students indicated that they wanted succinct summaries on transparencies and expected to be provided with the 'right' answer to set questions. One said:

'I was educated in a system where there is a right and a wrong answer and the teacher knows the right answer ... so follow her or copy if you want to get it right!' (Anonymous)

Many students gave similar responses. Another reported:

'I actually expected that the lecturer will be feeding us with information and we will take notes and go home and memorise them and wait for the test ... what frustrated me was having to put everything in my own sentences all the time ... I found it very hard not to regurgitate from the book.' (Anonymous)

Students found it hard to understand the purpose of learning tasks aimed at helping them clarify their existing knowledge each time a new section of learning content was started. What is more, the out-of-class learning tasks were particularly difficult, both in terms of using them and in terms of the frequency with which they had to be completed in order for students to submit their workbooks for assessment at the scheduled times during the semester. Students reported: 'I did not understand the purpose of the workbook. To complete the learning tasks take lots of time and critical thinking to understand the learning content.' We would link this finding 
with the notion of students' 'learning edge' (Wlodkowski 1999:28), in which they are challenged and encouraged toward critical reflection about their learning processes. In this study, however, we are arguing that both our strategies and the supportive learning environment we provide help students maintain the balance between discomfort and comfort in the transition to new ways of learning (see, for instance, Gravett \& Petersen 2009).

However, as the learning tasks had been structured carefully in order to guide students systematically and incrementally through the content, with each section building on the previous one for them to come to an understanding of the whole, the following comments were heartening:

'I have learnt that I had to read with understanding and tasks are to be written with my own words and with understanding, without plagiarism ...' (Anonymous)

'I was actively involved in my own learning. The learning tasks in the workbook forced me to engage deeply in this course and the learning content. The workbook helped me see how all the units in the module linked together and build on one another.' (Anonymous)

'I became more actively involved in all my learning tasks. They kept us continually engaged in the learning content and kept me working consistently. Completing the learning tasks helped me understand the work far earlier in the module than I generally do ... normally I start studying just before the examination and cram all the work I need to know.' (Anonymous)

Overall students' responses are consistent with the movement toward 'theoretical reflexivity' (Mezirow 2003), which involves changing one's underlying assumptions resulting in perspective transformation, which can also be described as changing one's positioning in the learning situation. We also see the alignment of this finding with the work of RuthSahd (2003:490), who ascribes a promotion of greater selfawareness to students' integration of theoretical concepts to practice and improvement in practice and draws attention to its potential for fostering critical and reflective practice in nursing education.

\section{Appreciating the value of small group interaction}

Students particularly seemed to appreciate the support provided by their peers during small group interaction. Working in small groups fits with the socioconstructivist notion of 'learning the culturally shared ways of understanding and talking about the world and reality' (Merriam et al. 2007:292). The following are examples of students' comments on this aspect:

\footnotetext{
'...working in groups was so wonderful and encouraging, since I could communicate freely and share my ideas with others students.' (Anonymous)

'As a shy person I did not feel comfortable and confident in talking in a big group like the classroom, but I can participate in small groups ... I can be actively involved. I feel confident ... that I can at least participate in a group discussion whereas before I would keep my opinions to myself.' (Anonymous)

'... there is a lot of social interaction and short discussions by small groups of students ... I think [it] taught me to be a critical thinker and to be able to apply the information.' (Anonymous)
}

For students to really be moved to transform their ways of thinking and doing they have to explore their views in a safe environment and it is our contention that small group interaction complemented by respectful interaction provides such a learning 'space'. These ideas are consistent with the notion of establishing positive social interdependence (Johnson \& Johnson 2009) amongst individuals in which the group works cooperatively toward shared goals. In this respect individuals are encouraged to enable each other's efforts to complete the learning tasks. It also speaks to Habermas's (1970) contention that the reflective process involves more than the individual and is, in fact, dialogic in nature.

Most importantly, the students' reflections by the end of the course indicate that they seemed to understand the significance of the pedagogy, especially for their own learning and for their professional practice as educators in a nursing context.

\section{Ethical considerations}

In undertaking this study, the researchers were aware that they were in a position to unduly influence the students to contribute to this research. The article thus adheres to the Declaration of Helsinki (World Medical Association 2013) on ethical procedures for research involving human participants. To address ethics in this research, the authors worked in accordance with the prescribed set of procedures laid down in the university's guidelines for conducting ethical research. The research proposal was submitted to the Faculty Ethics Committee for approval endorsed by an ethical clearance number: 2012-033. As part of this process, students were informed of the purpose of the research and were asked to provide signed consent forms for their responses to be utilised for research purposes. They were also informed that their participation was voluntary. There was little potential risk for students in participating as their responses were collected at the end of the course, when assessment marks had already been finalised, so could not impact on their success in the course. Finally, students were assured of confidentiality, the responses being anonymous so that no student could be identified by any of the data.

\section{Trustworthiness}

The issue of trustworthiness in this qualitative study is addressed by the logic and coherence of the interplay of the various elements of this article which examines students' reflections on their experiences of dialogic mediation as captured in their reflections as participants in a course. In the following sections we will reflect on the warrantability of this claim for the reader as we show how we have addressed the issues of validity and reliability in this research.

As teachers in education using a particular philosophical and theoretical basis for the pedagogy expounded on in this article, namely constructivist conceptualisations of learning, we clarify how these aspects have influenced both the 
design of the course and the posing of the research questions early in the article. This is in line with the ideas of Patton (2002), who stresses that the perspective and experiences of the researcher, as well as the philosophical basis which underpins the study, are two crucial elements which require attention if validity and reliability are to be ensured. In addition, in the description of the research design, including an account of how the research questions were aligned with it, we took cognisance of Henning et al. (2004), who pointed out that the primary function of a research design is to guide the gathering of evidence so that the research question(s) are clearly addressed.

Next, the volume of the raw data, as well as Tables 3 and 4 indicating the process of the flow of data analysis, reflect our attempts to be as explicit as was feasible about the processes of data analysis in order to give as much detail as possible about the inferences we drew from this and presented as findings. As we directed the generation of data and were solely responsible for data analysis we were careful to provide an in-depth description of steps during the processes of data analysis so as to enhance the credibility of the findings (Patton 2002). We tried to avoid researcher bias by first analysing the data separately and then comparing the analysed data before combining them in the findings. LeCompte and Preissle (1993:316) also pointed out that the key issue in assessing qualitative studies is to examine the steps a researcher takes in the process of setting research questions, collecting, analysing and interpreting data. This enables the provision of sufficient evidence to allow the reader to have confidence in the outcomes of the study (Maykut \& Morehouse 1994) or for the reader to check on the consistency between the results and the collected data (Merriam 2009). Ultimately, readers wish to know if a researcher has achieved a goodness of fit. LeCompte and Preissle (1993:318) indicated that one measure of this for researchers is to see whether they have stayed true to the 'practices, conventions, and principles of the discipline and the profession' in their work. These processes are reflected in the methodology section of this article, in particular in the sections where we indicate how we moved from student excerpts (raw data) to codes to categories to themes as are fitting in qualitative research of this nature. In addition in the presentation of the findings we provide copious 'raw' data to allow student voices to 'speak'. These aspects, we argue, help to establish a clear 'audit trail' (Merriam 2009) which helps to increase the validity and reliability of the research.

As this research was conducted with a defined population at a specific time in a particular institution, we are by no means making claims to generalisability. However, by providing ample detail of the course outline and structure and the various strategies we used within it, we are providing sufficient detail for readers to decide if the course itself and the inferences we draw from student data are reasonable and to determine if they could be adapted or transferred to other contexts.

\section{Discussion}

As educators of student nurses, the researchers realised that dialogic mediation posed challenges for students unaccustomed to the pedagogy, for various reasons. First of all, it was natural for them to approach the teaching and learning strategies associated with a new pedagogy with a measure of trepidation. As nursing practitioners, many also assumed that they did not know much about teaching and learning and were for this reason reluctant to express their views at the beginning. For the course educators, the large class of students in the group $(n=248)$, the barriers caused by language (students study in a second or third language) and the students' lack of knowledge about university-level expectations of the academic process, were also factors of concern. The researchers also realised that a semester was too short to address the foundational issues associated with the teaching and learning of critical-thinking skills that they hoped to address in this course. However, as discussed by Brooks (2011:44), students' struggles and challenges when encountering new knowledge or ways of learning is a precondition for their 'growth and transformation' and is not always time-dependent.

Despite the challenges that the students reported, positive indications presented in student reflections, as well as the success rate in the course, were key motivators for us as educators. In spite of this, caution is still warranted, especially at the beginning when a careful balance has to be maintained between managing students' frustration and challenging their existing, deeply-entrenched beliefs so that they did not get despondent. As hooks ${ }^{1}$ (2010:21) argues, under such circumstances students require a space where they can be 'honest, even radically open. They can name their fears, voice their resistance to thinking, speak out and they can also fully celebrate the moments where everything clicks and collective learning is taking place'. In managing this balance for students, structuring the course into its various phases was helpful. In the first phase, the dialogic process helped students to articulate their existing ideas about teaching and learning and served as an avenue to express their frustrations as they reflected on, challenged and explored their often unexamined views. The dialogic process was meant to trigger a feeling of disequilibrium so that students become aware that their previously-held ideas and views were perhaps no longer adequate for their own academic development and practice, and so that they were open to learning about different ideas. The authors equate this with the idea of moving students out of their 'comfort zones' (Borbye 2010:10).

However, this challenging and critical reflection of moving students out of their comfort zones for learning was only possible in an environment of care, respect and collaboration. As Brooks (2011:44) argues, such an environment likens a classroom to a cocoon in which respect and care from the educator help facilitate change. In pushing students toward this point, the educators had to earn their trust from the beginning of the course. In a group of up to 300 students, constant validations of student responses and encouragement to persevere when they felt fearful were paramount. The

1.hooks is spelt with a small ' $h$ '. As a feminist writer she does not capitalise her names (bell hooks) - it is aligned to hooks stance as a feminist, activist teacher and writer. 
educators spent considerable time in each lecture on building this relationship with their students. The use of learning tasks, each of which was based on an open question requiring thoughtful, original and gradually more challenging responses from the students, provided some measure of support for them. Students were able to participate freely during this demanding stage of their learning and it was here that the context of small group interaction - between three to five participants - was useful. Students were also able to offer each other support when they shared their views, frustrations and fears with each other in the group. The use of learning tasks also helped to keep their discussions about the learning content focused and structured.

Once students had examined their existing ideas they were introduced to new views about teaching and learning. In this process, careful sequencing of learning tasks, both in the classroom and in the workbooks, was again helpful. The learning tasks enabled reciprocal interaction, exploration, inquiry and theorising about the learning content, which is the type of educational dialogue essential for building new knowledge. They also created the space for students to reflect on the theoretical underpinning of the course, the educators' use of dialogic mediation in action and their experiences as students in the course. Also, the carefully sequenced learning tasks that students responded to in their workbooks helped to build understanding systematically, whilst at the same time encouraging them to adopt a critically-reflective stance to the learning content, which amounts to a multilayered form of reflection on the content. In addition, the workbooks provided them with a conceptual record of their engagement with a new pedagogy and its underlying foundations, serving as a resource for them to draw on. The integration of these varied aspects can be likened to making the educators' 'expert conceptual and organizational schemes' (Horii 2007:369) for the course explicit for students so as to better scaffold their learning. The researchers argue that this interaction between theory, practice and reflection served as a powerful resource on which to draw when implementing dialogic mediation.

\section{Limitations of the study}

Firstly, as educators working in teacher education and higher and adult education, teaching an education course to postbasic nursing students, the researchers are mindful that they are not professional nursing educators who have worked in the field for many years. They are thus wary that they may be interpreting the literature in the field of nursing education in an overly-simplified manner. Secondly, the use of student reflection data, although anonymous and collected after the completion of the course, may have been influenced by their interaction with the students as both lecturers and as researchers. Also, as researchers, researching the value of a course that they teach, they are aware that they may be reading the data from a particular perspective. They have tried to mitigate these areas of concern through the measures that they have taken to ensure rigour in the data analysis process. As already mentioned, the large class of students in the group ( $n=248)$, the students' primary language and their lack of knowledge about the academic process at university level, may have contributed more significantly than the course and pedagogy itself to students' initial frustrations which were a key finding of this study.

\section{Recommendations}

We believe that (based on student feedback) the difficulties the students first faced on encountering an unfamiliar pedagogy could be alleviated by allocating more time to the first half of the course. As we are constrained by the module credits and limitations of a conventional semester course of 14 weeks, it is not possible to lengthen the course itself. A second recommendation revolves around better alignment with the pedagogies in other modules in the same programme so that there is more coherence for students and improved understanding of the strategies and tools used. Such an approach is bound to create less learning dissonance for students.

\section{Conclusion}

This article has presented an account of post-basic nursing students' reflections of their engagement with the pedagogy of dialogic mediation and how the pedagogy influences their ideas of teaching and learning. The study followed a qualitative research approach in which the following research question was addressed: 'What are students' reflections of their experiences of dialogic mediation and the influence of this on their ideas of teaching and learning?' As educators working in teacher education and higher and adult education, teaching an education course to post-basic nursing students, the authors were prompted by the literature in the field of nursing education which speaks to the idea of creating learning situations and classroom conditions that use interactive dialogue, cooperation and problem-based pedagogies. As educationists, the authors drew also on their experience working with students in education for many years which has taught them that the majority tend to be comfortable with a transmission mode of teaching as maintained in a passive lecture-orientated mode and that it is a huge shift for students to adopt more active learning approaches and to find their footing in a pedagogy that promotes active critical thinking. The results of this study seem to endorse this. Almost all students initially expressed their frustrations with a pedagogy that expected them to take an active part in their own learning whilst they were accustomed to more passive forms of learning. However, the student data also shows a movement from frustration with dialogic mediation to understanding the value of the pedagogy and an appreciation of the value of small group interaction. This finding is promising as it indicates that it is possible, even in a short period of time, to begin to address mature students' ideas about teaching and learning, even when they have a predominant history of 'transmission mode' teaching and learning. This article was the researchers' attempt to contribute to the debate on promoting meaningful teaching and learning in nursing education and to invite discussion around the issues presented. 


\section{Acknowledgements}

We wish to acknowledge the significant contribution of Professor Sarah Gravett who was the original person to conceptualise and design the course and who gave permission for us to use the course material in this article. We also wish to acknowledge two anonymous reviewers in the field of nursing education as well as the two language editors, Dr Andrew Graham and Dr Graham Dampier, who provided extremely useful feedback that allowed us to revise the article a number of times.

\section{Competing interests}

A possible competing interest that we wish to declare is that we are contracted and remunerated by the School of Nursing at a Johannesburg-based university in order to provide this course for student nurses. We do not, however, believe that this research or article will have an undue influence on the continuation of this contract as we have been executing this work for the department for the last five years.

\section{Authors' contributions}

N.F.P. (University of Johannesburg) was the initiator of the article, was responsible for data collection and analysis, took charge of writing the first draft and contributed to further drafts of the article before submission to the journal. V.M. (University of Johannesburg) was responsible for data collection and analysis and contributed to the drafts of the article before submission to the journal.

\section{References}

Borbye, L., 2010, 'Out of the comfort zone. New ways to teach, learn and assess essential professional skills. An advancement in educational innovation', in $\mathrm{H}$ Higgs (ed.), Synthesis lectures on technology, management and entrepreneurship, Morgan and Claypool, San Francisco.

Brookfield, S.D., 2005, The power of critical theory, Jossey Bass, San Francisco.

Brooks, J.G., 2011, 'Bearing the weight: discomfort as a necessary condition for "less violent" and more equitable dialogic learning', Educational Foundations, WinterSpring 25(1-2), 43-62.

Burbules, N.C. \& Bruce, B.C., 2001, 'Theory and research on teaching as dialogue', in V. Richardson (ed.), Handbook of research on teaching, 4th edn., pp. 1102-1121 American Educational Research Association, Washington, DC.

Chabeli, M.M., 2007, 'Facilitating critical thinking within the nursing process framework: A literature review', Health SA Gesondheid 12(4), 69-89. http:// dx.doi.org/10.4102/hsag.v12i4.273

Forbes, M.O. \& Hickey, M.T., 2009, 'Curriculum reform in baccalaureate nursing education: Review of the literature', International Journal of Nursing Education Scholarship 6(1), 1-18. http://dx.doi.org/10.2202/1548-923X.1797, PMid:19725808

Garrison, D.R. \& Archer, W., 2000, A transactional perspective on teaching and learning. A framework for adult and higher education, Elsevier Science, Oxford.

Gravett, S., 2005, Adult learning. Designing and implementing learning events. A dialogic approach, 2nd edn., Van Schaik, Pretoria. PMCid:PMC1314899

Gravett, S. \& Petersen, N., 2009, 'Promoting dialogic teaching among higher education faculty in South Africa', in J. Mezirow, E.W. Taylor \& Associates (eds.), Transformative Learning in Practice: Insights from Community, Workplace, and Higher Education, pp. 100-110, Jossey Bass, San Francisco.

Habermas, J., 1970, Toward a rational society. Student protest science and politics, Beacon Press, Boston.

Harvath, T.A., 2008, Editorial, 'A culture of learning', Journal of Nursing Education 47(12) 535-536. http://dx.doi.org/10.3928/01484834-20081201-02, PMid:19112742

Henning, E., Van Rensburg, W.A. \& Smit, B., 2004, Finding your way in qualitative research, Van Schaik, Pretoria.
Hooks, ${ }^{2}$ b., 2010, Teaching critical thinking: practical wisdom, Routledge, New York.

Horii, C.V., 2007, 'Teaching insights from adult learning theory', Journal of Veterinary Medical Education, Fall 34(4), 369-376. http://dx.doi.org/10.3138/jvme.34.4.369, PMid:18287460

Jeffries, P.R., 2005, 'A Framework for designing, implementing, and evaluating simulations used as teaching strategies in nursing', Nursing Education Perspectives 26(2), 96-103.

Johnson, D.W. \& Johnson, R.T., 2009, 'Educational psychology success story: social interdependence theory and cooperative learning', Educational Researcher 38 , 365-379. http://dx.doi.org/10.3102/0013189X09339057

Kuiper, R.A. \& Pesut, D.J., 2004, 'Promoting cognitive and metacognitive reflective reasoning skills in nursing practice: Self-regulated learning theory', Journal reasoning skills in nursing practice: Self-regulated learning theory', Journal
of Advanced Nursing 45(4), 381-391. http://dx.doi.org/10.1046/j.1365of Advanced Nursing 45(4), 38

LeCompte, M.D. \& Preissle, J., 1993, Ethnography and qualitative design in educational research, 2nd edn., Academic Press, London. PMCid:PMC1195019

Maykut, P. \& Morehouse, R., 1994, Beginning qualitative research. A philosophical and practical guide, Falmer Press, London. PMid:7922901

Merriam, S.B., Caffarella, R.S. \& Baumgartner, L.M., 2007, Learning in adulthood: A comprehensive guide, 3rd edn., Jossey Bass, San Francisco.

Merriam, S.B., 2009, Qualitative research and case study applications in education. Revised and expanded from case study research in education, Jossey Bass, San Francisco.

Mezirow, J., 2003, 'Transformative learning as discourse', Journal of Transformative Education 1(1), 58-63. http://dx.doi.org/10.1177/1541344603252172

Mickelson, J.J., Kaplan, W.E. \& MacNeily, A.E., 2009, 'Active learning: a resident's reflection on the impact of a student-centred curriculum', Canadian Urological Association Journal 3(5), 399-402. PMid:19829736 PMCid:PMC2758515

Patton, M.Q., 2002, Qualitative research \& evaluation methods, 3rd edn., Sage Publications, California.

Popil, I., 2011, 'Promotion of critical thinking by using case studies as teaching method', Nurse Education Today 31(2), 204-207. http://dx.doi.org/10.1016/j. nedt.2010.06.002, PMid:20655632

Rowan, C.J., McCourt, C., Bick, D. \& Beake, S., 2007, 'Problem-based learning in midwivery - The teachers perspective', Nurse Education Today 27(2), 131-138. http://dx.doi.org/10.1016/j.nedt.2006.03.006, PMid:16759756

Russell, A.T., Comello, R.T. \& Wright, D.L., 2007, 'Teaching Strategies Promoting Active Learning in Healthcare Education', Journal of Education and Human Development, 1(1), viewed 05 July 2012, from http://www.scientificjournals.org/journals2007/ articles/1025.htm

Ruth-Sahd, L.A., 2003, 'Reflective practice: A critical analysis of data-based studies and implications for nursing education', Journal of Nursing Education 42(11), 488-497. PMid:14626387

Sandelowski, M., 2000, 'Focus on research methods: Combining qualitative and quantitative sampling, data collection, and analysis techniques in mixedmethod studies', Research in Nursing and Health 23(3), 246-255. http://dx.doi. org/10.1002/1098-240X(200006)23:3<246::AID-NUR9>3.0.CO;2-H

Shor, I. \& Freire, P.A., 1987, 'What is the "dialogical method" of teaching?', Journal of Education 169(3), 11-31

Tanner, C.A., 2009, Editorial, 'The case for cases. A pedagogy for developing habits of thought', Journal of Nursing Education 48(6), 299-300. http://dx.doi. org/10.3928/01484834-20090515-01, PMid:19552315

Taylor, E.W., 2007, 'An update of transformative learning theory: a critical review of the empirical research (1999-2005)', International Journal of Lifelong Education 26(2), 173-191. http://dx.doi.org/10.1080/02601370701219475

Thorne, S., Kirkham, S. R., \& MacDonald-Emes, J., 1997, 'Interpretive description A noncategorical qualitative alternative for developing nursing knowledge' Research in Nursing and Health 20(2), 169-177. http://dx.doi.org/10.1002/ (SICI)1098-240X(199704)20:2<169::AID-NUR9>3.0.CO;2-I

Van Dyk, A., Jooste, K., Small, L. \& Pretorius, L., 2005, 'The contribution of the clinical nurse instructor to the development of critical thinking skills of the student nurse in Namibia', Health SA Gesondheid 10(4), 16-28. http://dx.doi.org/10.4102/hsag. v10i4.204

Vella, J., 2008, On teaching and learning: Putting the principles and practices of dialogue education into action, Jossey Bass, San Francisco.

Wlodkowski, R.J., 1999, Enhancing adult motivation to learning: a comprehensive guide for teaching all adults, Jossey-Bass, San Francisco.

World Medical Association, 2013, 'Declaration of Helsinki - ethical principles for medical research Involving human subjects', viewed 05 July 2013, from http:// www.wma.net

Worrell, J.A. \& Profetto-McGrath, J., 2007, 'Critical thinking as an outcome of context-based learning among post RN students: A literature review', Nurse Education Today 27(5), 420-426. http://dx.doi.org/10.1016/j.nedt.2006.07.004, PMid:16945453

Yuan H., \& Williams, B.A, \& Fan, L., 2008, 'A systematic review of selected evidence on developing nursing students' critical thinking through problem-based learning', Nurse Education Today 28(6), 657-663. http://dx.doi.org/10.1016/j. nedt.2007.12.006, PMid:18267348

2.hooks is spelt with a small ' $h$ '. As a feminist writer she does not capitalise her names (bell hooks) - it is aligned to hooks stance as a feminist, activist teacher and writer. 